\title{
The fictional translator in Anglophone literatures
}

\author{
Beverley Curran \\ Aichi Shukutoku University, Nagoya
}

The use of English is commonly taken to be one of the distinctive features of globalization and Anglophone cultural hegemony. Is the appearance of the fictional translator in English writing an indication of deliberate resistance to "the global parochialism of Anglophone monoglossia" (Cronin 2003: 60)? Or are these imagined translators weak echoes of the same 'questions of colonialism and cultural hegemony' raised by Third World postcolonial plurilingual writers, writing in the language of the ex-colonizer? Are these characters the authors' wistful attempts to construct a bilingual consciousness denied them through assimilation? These are the overarching questions that this paper will attempt to answer by looking at the fictional translator as a character and linguistic presence in writing in English through an examination of Michael Ondaatje's The English Patient (1992), David Malouf's Remembering Babylon (1993), and Jonathan Safran Foer's Everything is Illuminated (2002). The presence of the fictional translator in Canadian, Australian, and American writing in English suggests that the agent of discursive migration is operative even within regions of stubborn Anglophone monoglossia. If translators are agents of change, how do they operate in Anglophone writing in late modernity? And why is their presence so often awkward, unreliable, and even painful? I will argue that the fictional translator registers anglophone angst in spite of the language's powerful global influence and publishing power.

\section{Introduction}

The fictional translators under consideration in this paper are found in different times and places, and what 'English' means shifts according to historical and geographical context. The translator in Ondaatje's The English Patient (henceforth parenthetically abbreviated as EP) is a gifted linguist and desert explorer, searching the Libyan Desert in the 1930s for a lost oasis. He effortlessly slips across borders and in and out of French, English, Arabic and desert dialects, before he is burnt beyond recognition in a plane crash. In the novel, English refers in linguistic, cultural, and geographical terms to the "fragile white island that with customs and manners and books and prefects and reason somehow converted the rest of the world" (EP 283), although, after the atomic bomb drops on Hiroshima and Nagasaki, the reference is wider:

American, French, I don't care. When you start bombing the brown races of the world, you're an Englishman. You had King Leopold of Belgium and now 
you have fucking Harry Truman of the USA. You all learned it from the English. (EP 286)

The fictional translator is deeply implicated in the colonizing process and its destructive racist policies, his erudition and assumption of autonomy dated.

Malouf's Remembering Babylon (abbreviated as RB) takes place roughly eighty years earlier, in the mid-nineteenth century in northern Queensland. The translator intrudes into a group of white settlers whose tight community bonds hold back fears stemming from being unwelcome intruders themselves. The sudden appearance of Gemmy Fairley in their midst places "in question nearly everything that seems to be unquestionable to the members of the [...] group" (Alfred Schutz; qtd. in Cronin 2000: 45). Like the English patient, Malouf's fictional translator is initially unidentifiable. In this case, he at first appears to be "a black", and then a thing "not even, maybe, human" ( $R B 2$ ), a bird or a bewitched being whose transformance into a bird had been arrested in the process and was "neither one thing nor the other" (ibid.). Gender, too, is unclear, although when "it" speaks a stuttering English - "'Do not shoot,' it shouted. 'I am a B-b-british object!"” $(R B 3)$ - identity hardens into that of a white man. However, the English is followed by an utterance in "some whining blackfeller's lingo" $(R B 4)$, and the fear of the Other is replaced by fear of another language: if they "allowed the man to go on using it, he would see how weak they were and get the advantage of them" $(R B 5)$. When the settlers have a good look at the intruder, they find "a man who had suffered a great deal of damage" (RB 7), with singed and smudged features, blackened teeth and a short twisted leg. Like most of the settlers themselves, who had left hard lives in Scottish mining towns, Gemmy had escaped life as a "maggot" on the factory floors of an industrialized London by climbing on a ship, but without knowing where it was bound. Thrown overboard and washed up on an unknown shore, Gemmy Fairley survives by letting go of the English he knew and finding a sense of belonging through the acquisition of Aboriginal languages. His temporary re-entry into English-speaking society as a translator causes cultural crisis, as Gentzler (1996: 117) suggests, and initiates change. This is indeed the role that Malouf intends Gemmy Fairley to have in his novel: "I wanted to introduce [...] a kind of catalyst" (Papastergiades 1993: 88), he explains, to accelerate the realization among the settler community that migrancy might entail a shift in consciousness and language.

America, rather than England, is the source of the English that informs the translator in Foer's Everything is Illuminated (abbreviated as EiI). Alexander Perchov lives in Odessa and his idiosyncratic American English seems initially to follow the convention of the 'funny foreigner' in travel literature (Cronin 2000: 46), the inept foreign speaker of English whose language can amuse and also accommodate the monolingual anglophone reader. The translator interacts in conversation and correspondence with a young American writer, who, with the help of a photograph, is look- 
ing for a woman who may have saved his grandfather from being a victim of Nazi genocide. Alex is Ukrainian, a post-colonial subject in another configuration of East-West, and his urban mix of Ukrainian and Russian, as well as his American English, speaks not only of significant shifts in post-Soviet times, and earlier stories erased in earlier border shifting, but also the influence of the Internet.

In each novel, the fictional translators can be found at the centre of powerful historical and cultural tensions. It is important to bear in mind, however, that the temporal and spatial location of this 'centre' is nebulous in a world marked by the global movement of travellers, economic migrants, military troops, refugees, and the displaced. Instead of distinct source and target cultures, as usually theorized in western translation studies, the translator is located amid evolving languages and developing cultural identities. Edwin Gentzler (2002: 9) specifically locates this kind of translation activity in the Americas:

[T]ranslation in the Americas is less something that happens between separate and distinct cultures, and more something that happens between and/or among different but often interconnected hybrid cultures, full of multiple clandestine groups, including indigenous groups, colonists, expatriates, immigrants, thieves, mestizos, and other marginal minorities.

In a sense, Gentzler does not go quite far enough. I would suggest the Antipodes as well as "the Americas" locate translation where "native indigenous tribes and languages, combined with immigration and globalization patterns characterize the linguistic makeup" (Gentzler 2002: 8). The appearance of a fictional translator in anglophone writing out of these locations embeds a sense of multilingualism in domestic terms, but often as a kind of smothered tongue. At the same time it positions the writing in global terms with other languages. The fictional translators in the novels of Ondaatje, Malouf, and Foer reconfigure and reposition not only other kinds of literatures written in English, but also translated texts read in English, especially texts coming from South America and Eastern Europe. The translator stands in for collectivity, gives a sense of 'we', which is not 'we, the people' in a national sense, but a planetary one.

\section{The English Patient}

In his discussion of the fictional turn in translation studies in "What's Different about Translation in the Americas?", Gentzler (2002) distinguishes resistance in writers against those who "reify European text, laws, music, culture, art and social form in the New World" (14), that is, former colonies now consisting mainly of multicultural immigrant populations. Ondaatje's fiction is surely part of this resistance. He sets his story in Europe, but peoples it with a Hungarian count, Almásy, who prefers the status of a nationless 'international bastard', an Italian Canadian thief with the telling 
name of Caravaggio, a Canadian nurse, and a Sikh who is a soldier in the British army. That is, none of these English speakers are 'English'. Two of the four, Almásy and Caravaggio, have drug dependencies, and all four are loners who could be linked to marginal or underground communities. Further, Gentzler points out, while translation in the Americas is ubiquitous it is so "often in a way that Euro-centric models cannot detect" (16). In the fictional world of The English Patient, British Intelligence cannot identify the translator, either.

Ondaatje's novel takes place in a ruined villa in Tuscany as World War II wanes and troops move northward. Hana, a young Canadian nurse, has decided to remain behind and care for a single patient burnt beyond any identification. Her 'English patient' lies immobile, dependent on morphine and memories of the desert and the married woman he loved. These two are later joined by Kirpal Singh, an Indian soldier dismantling mines for the British army; and David Carvaggio, an Italian-Canadian whose skills as a thief and an Italian speaker have been put to use by Allied Intelligence. Ondaatje stresses the anonymity attached to all these characters. The patient is known only by the language he speaks; the Sikh sapper is not only part of the "anonymous machinery of the army" (EP 195) but also an "anonymous member of another race, a part of the invisible world" (196) colonized but still unrecognized by the acquisitive West. The nurse keeps her emotional distance from everyone, and the thief is part of the underground economy. All four characters use invisibility as a strategy for survival. Their disparate histories and shared invisibility configure the interlingual and cultural overlap that seethes under the veneer of English, which characterizes the site of translation in the Americas and the Antipodes.

Until Caravaggio arrives at the villa in search of Hana and with information about "a Hungarian named Almásy" (EP 163), the burn victim is referred to in the text as "the English patient", "the Englishman", "the burned patient", "white translator of guns", "a despairing saint", and "a ghost", but not by name. When interrogated by the British in 1944, the patient's charred condition and inability or unwillingness to identify himself were not exceptional: "At that time of the war there were hundreds of soldiers lost from themselves, more innocent than devious. [...] The burned pilot was one more enigma, with no identification, unrecognizable" (95). He played with their inability to identify him as a traitor or ally, but the interrogating officers found "[e]verything about him was very English except for the fact that his skin was tarred black, a bogman from history" (96). The illegible body, untranslatable, is an obstacle to recognition. The interroga-tors construct their knowledge based on assumptions about 'English' as a national identity manifest in native command of the language. Almásy is able to exploit that assumption to avoid detection. Much later it turns out that his tongue has furnished very effective linguistic camouflage, for "the English patient is not English" (163), but a Hungarian count, Ladislaus de Almásy, one of the great desert explorers, who acted as a desert guide for German spies during the war. 
Being Hungarian suggests that Almásy speaks 'in translation' throughout this novel. In spite of his formidable linguistic gifts, he is in the double bind of any minority language translator: letting a dominant language like English take over, he becomes less and less 'recognizable'; resisting the powerful dynamic, however, can mean being sidelined in linguistic stasis. The use of English is commonly taken to be one of the distinctive features of globalization and Anglophone cultural hegemony. The fictional translator in Ondaatje's The English Patient is a complex and suggestive construction that positions translation as a process carried out by non-native English speakers, which means that these agents are always in translation themselves. This condition, however, can also be applied to culturally assimi-lated Anglophones in Canada, America or Australia, whose English language is neither spoken in its original form nor located in situ.

Minority translation has been identified as "the single most important issue in translation studies today" (Cronin 2003: 144). In the global economy, the direction of translation has been largely out of English, especially in terms of technical translation. An historical imbalance in learning has been a general result, with, for example, "citizens of Indonesia or the Caribbean nations know [ing] much more about Europe than Europeans generally know about Indonesia or the Caribbean" (Brennan 2001: 52). Minority languages seem dependent on more powerful ones but in Ondaatje, the opposite seems to be implied. The dependent patient is 'English', and his touchstone text is a translation of Herodotus. Translations prop up and sustain English, and always have.

It can also be said that widely read translations exert considerable influence on monolingual Anglophone cultures and cultural production. As Timothy Brennan (2001: 57) points out:

[I]t has become plausible to argue that among the most defining works of postwar US fiction are works written originally in other languages but which carved out a space, in translation, in the US literary canon. Certain books like One Hundred Years of Solitude, [...] The Name of the Rose, [and] If on a Winter's Night a Traveler are "American" books to their North American readers and part of a national/political canon.

Brennan bases his observation on Anglophone readers in the United States, but it is applicable as well to the impact the works of Márquez, Eco and Calvino have had on Anglophone readers in Canada or Australia. Ondaatje, for example, calls One Hundred Years of Solitude "the bible book of the twentieth century" (1978: 21) in a discussion based on his reading of Gregory Rabassa's translation. These well-known literary works are not mistaken as local texts, but "their foreignness occurs [...] entirely in English" (Brennan 2001: 58). Further, a translation like this influences Anglophone writers who read the novel in translation and then "cop [sic] the gestures" (59) in their own works in English.

It is worth noticing that the influential translations Brennan mentions all deal explicitly with cultural and linguistic translation. Monolingual 
Anglophone readers may get a sense of translation as a way to pass on stories of another time and tongue, as well as alternative values. However, because of historical and linguistic blockage and loss, the monolingual writer may feel compelled to create a fictional translator who is tongue-tied, a narrative under constraint, or a form that is 'experimental' and not easily accessible. In this way, the translation of fiction and fictional translation are both surfaces which serve to stage the complex cultural interface of countries marked by colonization, immigration, and linguistic hegemony which leads to shedding first languages and cultural assimilation.

The ragtag fugitive community in the villa in Tuscany is linked with a literary one that includes Herodotus, Kipling, Tolstoy, and Pound. Each of these writers can be linked with a different temporal or spatial empire. Almásy carries Herodotus with him everywhere as "his guidebook, ancient and modern, of supposed lies" (EP 246). This is a fitting imperial conflation: the Greek and British empires shared a similar attitude towards language acquisition. In Alien Wisdom: The Limits of Hellenization, Arnoldo Mommigliano explains that whereas educated Romans "all learned Greek and other foreign languages at the time, the Greeks [...] were so imbued with their cultural superiority, that they never bothered to learn anybody else's language" (qtd. in Kramsch 2002: 1245). Herodotus, for example, likens the sound of Arabic to "the screeching of bats" (EP 140), but the English patient still imagines his literary mentor in the guise of a desert storyteller:

I see him as one of those spare men of the desert who travel from oasis to oasis, trading legends as if it is the exchange of seeds, consuming everything without suspicion, piecing together a mirage. 'This history of mine,' Herodotus says, 'has from the beginning sought out the supplementary to the main argument.' What you find in him are cul-de-sacs within the sweep of history - how people betray each other for the sake of nations, how people fall in love... (119)

Almásy measures the stories against his own experiences and other readings, and when he finds contradictions he corrects them: "When he discovered the truth to what had seemed a lie, he brought his glue pot and pasted in a map or news clipping or used a blank space in the book to sketch" (246). The fictional translator thus creates a collage in which, like the practice of comparing an original and a translation, puts versions up against each other for critical comparison.

Inscribed in this mix, as well, is a modernist tradition of translation, typified by Ezra Pound, a figure in which the issues of textual fidelity and national allegiances are truly entangled. The autodidactic nature of the English patient's erudition resonates in Pound's idiosyncratic approach to translation. As Lawrence Venuti (2000: 12) describes it, "[t]he relation Pound establishes between his translations and the foreign text is partial, both incomplete and slanted toward what interests him". In The English Patient, the collocation between Pound and Almásy, as well as between treason and translation, is established by locating them in the same war prison- 
ers' camp, incarcerated and under interrogation. Pound's thoughts on translation offer another way to read the fire-damaged skin of the English patient. In his 1929 essay "Guido's Relations", Pound (2000: 28) maintains that it was not the foreign language that "obfuscated" his attempts at translation, but rather intralingual interference; "the crust of dead English, the sediment present in my own available vocabulary". For Pound the only way around this blockage was to stop thinking of language as a continuum and instead view it as a series of languages rendering a person culturally dependent until she or he made a language of their own. In this way, translation becomes a creative process to find new language whenever "there is no ready-made verbal pigment" (Pound 2000: 33). Caravaggio employs a similar strategy in his search to clarify the identity of the English patient, or, alternatively, to "perhaps invent a skin for him, the way tannic acid camouflages a burned man's rawness" (EP 117).

Location must also be considered in the construction of the fictional translator in The English Patient. The Tuscany villa is a setting local to none of the characters, although Caravaggio can claim Italian heritage, and they all carry other cultures and memories with them. None of the English speakers in the novel are English in national terms. Their use of the language is a result of formal or pragmatic language education in British colonies. This sense of speaking English as an other language is a feature of the fictional translator being imagined by monolingual Anglophone writers. The 'multicultural phenomenon' found in the Americas and the Antipodes includes indigenous languages, official bi- and monolingualism, and a mix of languages, which do not equate language with nation, but rather with complex cultural interfaces and movement in multiple directions.

\section{Remembering Babylon}

Colonization has always had its multiple versions of England and English. In A Small Place, Jamaica Kincaid (1988: 24) puts it this way:

[E]verywhere [the English] went they turned it into England; and everybody they met they turned English. But no place could ever really be England, and nobody who did not look exactly like them would ever be English, so you can imagine the destruction of people and land that came from that.

In this description of the imposition of English elsewhere, there is an implicit link being made between racist colonial policies and social hierarchies and their dire effects on the environment. A radical shift in attitude concerning our place in the planetary eco-system may necessarily include a "seriously revised ecology of language" to "save all our skins" (Pratt 2002: 1287). In Remembering Babylon, Malouf supports this idea and his fictional translator by embedding language within the natural environment, an integrated rather than separate sign system. Colonization damages the people 
living in the invaded land, those who arrive, and the land itself. Poet John Daniels says, "[d]amaged nature is very valuable because it shows us ourselves" (Satterlee 2004: 170), and a damaged translator seems to have a similar function in Malouf's novel.

Language learning, Malouf suggests, is a way to link up with the land. In Australia, English was imported long after the land had already been imagined into being by other tongues and shaped by the ways of other cultures. The settlers were unable to recognize this shape because the land was empty of their things and their names. Malouf has pointed out that the English language in Australia does not "have its origin in a fact of place":

We've brought this language here, and we've made it apply to a world that is very different. It makes us more self-conscious about language and the uses of language, $[\ldots]$ and ought to make us more conscious of language as something which is partly willed rather than simply natural. (Papastergiadis 1993: 85)

If English is the crucial social glue that holds immigrant peoples together in Australia, it has not attached them to the land but rather to a chronic sense of dislocation.

In an ostensibly monolingual society where English is dominant, what kind of status does the translator have? More specifically, where is "the translator as a social being" (Hermans 1996: 25) located in Australia? Remembering Babylon focuses on the fear that the translator's knowledge of other languages and cultures creates within a small English-speaking enclave in nineteenth-century Queensland. Gemmy Fairley suddenly appears in Comet River as an utterly translated 'white' man and unleashes communal anxieties about the fragility of an identity built on the idea that power adheres to "white" and "English" in a place where the land does not inflect or reflect either of these terms. The fear evoked by the translator is not confined to the fictional fledgling community, of course. It is recognizable in contemporary monolingual societies suspicious of those whose languages are not understood. This fear can escalate to the extent that the language can become a "national security concern [and] its speakers [...] defined as enemies" (Pratt 2004: 422). Malouf foregrounds the figure of the translator to confront Anglophone Australia's fear of other languages, but that is not his sole concern. He also sets about to show the value of learning another language for a purpose other than to confront the enemy or counter security threats.

In Room for Maneuver, Ross Chambers locates the issue of land rights - "the historical dispossession by the European invasion of land that had been occupied for 40,000 years by Aboriginal people and in relation to which their cultural identity was defined" - at the heart of Australian history since colonialism (Chambers 1991: 246). Remembering Babylon was published in 1993, the year after the Mabo v. Queensland trial ended in a decision that refuted "the legal fiction on which the whole edifice of real 
property law came to be based in Australia" (Goodall 1996: 106). As Brittan (2002: 1159) puts it,

Mabo established, for the first time in Australian history, that the continent was not terra nullius (land belonging to no one) when the First Fleet arrived at Botany Bay in 1788 and that native land title was not automatically extinguished when James Cook took possession of the continent on behalf of the British Empire in 1770.

Just as the Mabo ruling was a retroactive challenge to colonial claims of possession (ibid.), so Malouf looks back to consider how one might enter a world without asserting and enforcing ownership.

It has been suggested that the fear that Gemmy instills in the Comet River residents stems from his racial ambiguity "but also, and crucially from the threat posed by his pidgin stuttering speech" (Brittan 2002: 1160). I agree that racial ambiguity is a source of fear in the community:

He had started out white. No question. When he fell in with the blacks - at thirteen, was it? - he had been like any other child, one of their own for instance. (That was hard to swallow.) But had he remained white? [...] Could you lose it? Not just language, but it. It." (RB 40)

Gemmy's struggle with English - his first language - is indicative of the extent of transformation possible in a man - in a white man, translated away from whiteness - and thus is very disturbing to the settlers:

They looked at their own children, even the smallest of them chattering away, entirely at home in their tongue, then heard the mere half-dozen words of English this fellow could cough up, and even those so mismanaged and distorted you could barely guess what he was on about. (ibid.)

He does not sound white, which means he does not really speak English, and he does not look 'right', that is, white, either. "The whole cast of his face gave him the look of one of Them. How was that then?" (ibid.). It is a face, it is suggested, shaped by the languages he has learned to speak.

But what Gemmy speaks is not pidgin. Pidgin languages (thus named after the Chinese (mis)pronunciation of the English word "business") are contact languages that developed out of commercial activities between traders whose languages were mutually unintelligible. They were "improvised along cultural borderlines" (Pratt 1992: 6) to facilitate communication, particularly for the purposes of commerce. As such, they need to be recognizable and understandable. Like Ogden's Basic English, pidgin has a sharply curtailed vocabulary and simple grammatical structure. But Gemmy's English is not border talk:

If you gave him a word for a thing, he could, after a good deal of huffing and blowing, repeat it, but the next time round you had to teach it to him all over again. He was imitation gone wrong, and the mere sight of it put you wrong too, made the whole business somehow foolish and open to doubt. (RB 39) 
Yet he had been "living off the land, learning their lingo and all their secrets, all their abominations they went in for" to the extent that he now spoke five languages, his commitment obvious in the cast of his jaw which "had adapted itself to the new sounds it had to make" (40). In other words, it is not his stammering English that poses a threat, but his other languages.

The question of Gemmy's loyalty is an important one for the white community of Comet River, and Gemmy recognizes that he must be selective about the information he shares. He is aware that this group sees him as a possible informant and when they attempt to pick his brains about the whereabouts of Aboriginal people in the vicinity, he deliberately skews the information he gives. At other times, though, he is simply incapable of furnishing the information desired because his listeners lack the necessary language:

In fact, a good deal of what they were after he could not have told, even if he had wanted to, for the simplest reason that there were no words for it in their tongue; yet when as sometimes happened he fell back on a native word, the only one that could express it, their eyes went hard, as if the mere existence of a language they did not know was a provocation, a way of making them helpless. He did not intend it that way, but he too saw that it might be true. There was no way of existing in this land, or of making your way through it, unless you took it into yourself, discovered on your breath, the sounds that linked up all the various parts of it and made them one. (65)

The limits of translation can be offset by a willingness to engage in language learning. Fear of languages, on the other hand, and suspicion of the translator leads to linguistic damage, physical violence, and ecological degradation and estrangement.

In formal education in multicultural countries such as Australia or the United States, the power of English is promoted. It is "the elite language that other language speakers aspire to master, as an indispensable means of access to cultural and other forms of capital" (Stanton 2002: 1268). In the universities, animated discussion of difference with regard to sex, gender, race and ethnicity take place primarily in a single tongue, namely English. And yet, for a growing number of students, in particular, and citizens, more generally, "English is a foreign, a second, an international, or a global language, not the language of a unitary mother tongue and culture" (Kramsch 2002: 1245). In Remembering Babylon, Malouf implicitly juxtaposes Gemmy's profound acquisition of language with that of the settlement's schoolteacher, George Abbot. When Jacques Derrida (1998: 42) recalls his childhood in Algeria learning French in school, "the master took the form, primarily and particularly, of the schoolteacher". In Malouf's novel, the "language of the master" is English, but it is a foreign language as it is taught by the English schoolteacher, with no relevance or resonance in the students' rough real lives in Queensland. Abbott is contemptuous and despairing of his charges' cultural illiteracy but continues to insist on their memorization of 
Shelley's poetry and the spelling of words like "mettlesome, benign, decorum, prudence" ( $R B$ 45). In his own free time, Abbot reads his foreign book, "usually a French one" (81), in order to transport himself from this place which he detests for its lack of refinement.

The schoolteacher's attitude is in striking contrast to Mr Frazer, the settlement's minister, who is deeply interested in the natural world and the chances of revelations found within it. As a street child, Gemmy's survival skills included a gift for mimicry and he puts it to use when he finds himself in a new world:

Relying on a wit that was instinctive to him and had been sharpened under harder circumstances than these, he let himself be gathered into a world which, though he was alarmed at first by its wildness, proved no different in essence from his previous one. (26)

Mr Frazer, his ad hoc interpreter, has no such linguistic knack:

He did not open his mouth wide enough, or his tongue was in the wrong place or lolled about like a parrot's, or he put too much spit into the thing or too little. Gemmy was glad that none of the clan were there to hear it. (67)

Further, the minister's interests in the world he asks Gemmy to show him are often embarrassing, for Frazer is concerned with "women's business" and oblivious to the taboos attached to uttering words never "heard on a man's lips" (ibid.). However, seeing this "queer whitefella" painstakingly draw exquisite pictures of local flora, Gemmy finds "satisfaction [at] the cooperation between them that made him the hands and eyes of the enterprise, the breath too when it came to giving things a name, as Mr Frazer was the agency for translating it out of that dimension, which was all effort, sweat and dirt [...] into these outlines on the page that were all pure spirit" (66).

In his only deliberate performances as a translator in the novel, Gemmy teaches the minister the names of plants, but with several different Aboriginal languages in his head, he "has to ask himself which of those worlds he's going to let Mr Frazer glimpse by giving him the name of the plant" (Papastergiadis 1993: 92). He also has to conceal things from $\mathrm{Mr}$ Frazer out of reverence and caution, and does not point out things "it was forbidden them to touch, since they were in the care of men whose land they were crossing" ( $R B$ 69). Neither does he indicate those plants that only women can approach nor those "that were a source of more power than he could control" ( $R B$ 69). This collaboration of translation and language learning is a profound shift to reading and writing the world in another way, from another direction, and with different intent. Less important than learning to speak is learning to listen carefully to voices and to the silence. This version of the fictional translator in Anglophone writing is a translator with ecological interdependencies. 


\section{Everything is Illuminated}

Like the two novels I have just looked at, Everything is Illuminated is a particular engagement with colonialism. The English Patient assumes a "classic" colonial position, where "long-distance but nonetheless strong political, economic, military, and cultural control is exercised over people taken as inferior" (Moore 2001: 118), like the British in India. The colonial pattern in Remembering Babylon is distinguished by invasive settlement and the subjugation of indigenous peoples, although Australia's colonial pattern was not typical in its officially rendering the continent empty in order to claim ownership of the land, and also by the experiment of colonization by criminals. A third kind of dynastic colonization, where "a power conquers neighbor peoples" (ibid.) marks Russian expansionism, although it is significantly reconfigured in the post WW II annexation of eastern and central European nations between 1948 and 1989-91. Jonathan Safran Foer's Everything is Illuminated takes place in the Ukraine in the wake of the dissolution of the Second World. The quest for "language adequate to the events that swept the Soviet Union" (Ram 1995: 199) joins an earlier and ongoing search for a way to express the horrors of the Second World War. The mayor of Hiroshima, Akiba Tadatoshi, said during the 2004 memorial service for A-bomb victims that "[t]he human race still lacks both a lexicon capable of fully expressing that disaster and sufficient imagination to fill that gap" (The Daily Yomiuri, 7 August 2004, p. 3), and his remarks are applicable, as well, to the Nazi genocide of the Jews.

Foer's fictional translator Alexander Perchov is Ukrainian and lives in Odessa. He works as a translator for his father's travel agency, Heritage Touring, whose clientele consists of "Jewish people [...] who have cravings to leave that ennobled country America and visit humble towns in Poland and Ukraine. Father's agency scores a translator, guide and driver for the Jews, who try to unearth places where their families once existed" (EiI 2-3). Alex has lied to his father about his English abilities - "'I am fluid,' I told him" (4), but is franker to Jonathan Safran Foer, a young Jewish writer who is visiting the Ukraine in an attempt to find a woman who may have saved his grandfather from the Nazis. Jonathan wants to go to Trachimbrod, the shtetl of his grandfather, to "see what it's like, how my grandfather grew up, where I would be now if it weren't for the war" (59). This novel makes explicit the collaboration between the (fictionalized) monolingual Anglophone writer and translator in the telling of a story neither has sufficient words for. The translator counters a hum from survivors of pogroms and other persecutions that "seem[s] dead set on preventing silence or linguistic meaning" (203) with a creative syntax and "nonapproximate vocabulary [and] nonsense words" (203) that approach what is suspended in traumatic memory. The fictional translator's willingness to speak nonsense en route to possible meaning is a staging of "what language can only point at" (Spivak 2000: 403). 
The New York Times and Washington Post reviews of Foer's novel compared it to A Clockwork Orange in its "verbal cunning" and "brilliant" energizing of the English language (Frazer 2002). The cunning brilliance of Burgess's novel is actually based on a very simple substitution of Russian words for English; thus "friends" become "droogs". In other words, familiarity with Russian makes A Clockwork Orange look like a one-trick pony. In Everything is Illuminated, the slapstick of much of the action, like the comic syntax of Alex's speech, may initially give the same impression, but the narrative style is a kind of frenetic camouflage that keeps the reader from taking the story too seriously until the translator's voice and linguistic strategies illuminate for the reader his or her own entanglement in the complex historical predicament of late modernity. Laughter suddenly dies in this novel, when there is the realization of how much has been suppressed and forgotten, and how many lies have been told, because the real story of Trachimbrod - and a person's part in it - is just too terrible to remember, let alone tell. Life in the village of Trachimbrod from the late eighteenth century to the early 1940s is a swirl of entangled stories that all connect, but by 1997, when Jonathan is looking for traces of the town, there seems to be none left, and no local knowledge of its existence. They work on and towards the same story from different departure points, feeling their way, but when the story starts to come into view, it is the writer who turns away, and the translator who continues to listen.

The past and its translation into cultural memory or traumatic withholding are not the only preoccupations of this novel. It is also a real meditation on how we dream of the future. Alex wants to take his brother Little Igor and go to the States, escaping Odessa and thus their father, who knocks everything over, including them, when he stumbles in drunk at night. It is a secret dream that Alex confides only in his letters to Jonathan. Alex pretends to go out with women to exclusive discos, but actually spends long evenings at the beach instead, so he can save his money for passage and a place that he and his brother can share in America. The absence of information about Trachimbrod and its former inhabitants stands in stark contrast to the excess of information available about the good life in America, from commodities like "blue jeans and white bread and delicate toilet paper" (EiI 33) to icons of pop culture. Entertainment and tourism are transnational industries that draw consumers from all over the world. Jonathan presumably books his tour over the Internet; Alex is probably watching music videos. Ondaatje and Malouf inscribed questions about the identity of 'English' in their novels and their figures of the fictional translator. Here, too, there are identity issues. Jonathan is an American Jew, but, to Alex, he "does not appear like the Americans I witnessed in magazines, with yellow hairs and muscles, or the Jews from history books, with no hairs and prominent bones" (32). Similarly, Jonathan speaks American English, but it is punctuated with Yiddish, which carries the trace of history erased with the eradication of the town of Trachimbrod. 
Alex and his grandfather, as translator and driver for the monolingual American writer seeking a story, replicate an arrangement that typifies the foreign journalist in areas of conflict. The Times correspondent Stephen Farrell describes the linguistic and somatic camouflage that Iraqi translators offer the British journalist covering the war. While he rides in the back seat of an "invisible" Korean car, "[t]wo Iraqis [sit] in the front seat, driver and translator, to satisfy casual observers" (Farrell 2004: 14). Both local translators and foreign journalists refrain from the use of English in public. In Foer's novel, Alex urges Jonathan to remain silent while he deals with staff in the hotel or makes inquiries in rural communities. In fact, Alex's own urban "fusion of Russian and Ukrainian" (EiI 112) causes suspicion and stirs hostility based on class consciousness and resentment over the sense of superiority city dwellers exercise over those in the countryside. "I commanded the hero [Jonathan] not to speak, because at times people who speak Ukrainian who hate people who speak a fusion of Russian and Ukrainian also hate people who speak English" (112). Animosities fall into recognizable polarities: the West, urban, hybrid, mobile English speakers vs. the East, rural, place identified, Ukrainian-only speakers, now likely configured as the global vs. local, but monolingualism is xenophobic everywhere.

As a fictional translator of erratic linguistic means but great heart, Alex is a figure that rattles "a hierarchy of high and low, lettered and unlettered, elite and vernacular" (Pratt 2004: 425) in a way that the American writer within the story is unable to match. Foer's novel suggests the translator is willing to go further than the writer. When Jonathan, Alex, and his grandfather finally find a survivor who can tell the story of Trachimbrod, it is Jonathan who does not want to listen. "'I don't want to hear any more,' the hero said, so it was at this point that I ceased translating" (EiI 186), but Alex keeps listening and records the story of how his own grandfather out of fear for his life betrays his best friend as a Jew to German soldiers who kill him. It is the translator who takes the responsibility for relaying the testimony that the writer seeks but cannot face, although the tragic story unexpectedly has turned out to implicate both of them. The moral paralysis he uncovers is not, of course, just that of Alex's grandfather or the cowed local community, but part of a global story. It resonates, for example, in the refusal of US immigration officials to let the Jewish aboard the New Ancestry land at Ellis Island. The ship's passengers all wind up in Treblinka.

Alex is a figure of bravery, unafraid of interacting in another language despite the ever-present risk of making linguistic howlers, and ready to hear stories that are being told. Even beyond the stories' lacerating endings, he continues to ponder their deeply troubling implications. The translator admits what the writer hides even in his own life. For example, Alex listens to Jonathan talk about his childhood and spending Friday nights at his grandmother's house. " "Tell me more about these Fridays. [...]' 'I think I'm done talking.' 'You must talk"' (158-9). At Alex's urging, Jonathan remembers standing with her grandmother on the back porch, each screaming the 
longest words they could think of. Jonathan screamed in English, and his grandmother, Yiddish. Alex asks:

\begin{abstract}
"What were the words that she would scream?" "I don't know. I never knew what they meant. I can still hear her." He screamed a Yiddish word into the street. "Why did you not ask her what the words meant?" "I was afraid." "Of what were you afraid?" "I don't know. I was just too afraid. I knew I wasn't supposed to ask, so I didn't." "Perhaps she desired for you to ask." "No." "Perhaps she needed you to ask, because if you didn't ask, she could not tell you." "No." "Perhaps she was shouting Ask me! Ask me what I'm shouting!" (159)
\end{abstract}

The translator insists on reading further, speculating on the possibilities in the grandmother's shouting silence. Foer is constructing not just an active and lovingly attentive reader in Alex, but perhaps a prototype of an activist translator, who admits involvement in lieu of the questionable ethics of attempting neutrality.

\title{
4. Conclusion
}

I would like to return to the questions posed at the start of this paper concerning the appearance of the fictional translator in anglophone writing in Canada, Australia, and the United States. The figure in the novels of Ondaatje, Malouf, and Foer all resist in different ways the local parochialism and global hegemony of English. The translator's presence in the novels makes clear that the world is not becoming more English-speaking, but more multilingual (Pratt 2002: 1287). Literary works of postcolonial plurilingual writers and their translations have certainly been influential in terms of style, theme, and linguistic awareness. However, there is also an environmental dimension to the fictional translator, which marks translation as a process that is ecological as well as political. Indigenous insistence on connections with the land seems a powerful influence here. Malouf's novel was published in 1993, the International Year of World Indigenous People. Ondaatje's was published in 1992, two years after both the doomed Meech Lake Accord brought indigenous language issues forward in bilingual Canada (Shoemaker 1996: 246) and "the most dramatic native Canadian protest of the twentieth century" (Shoemaker 1996: 253), the Mohawk Band's two-month blockade of the Mercier Bridge in Oka, Quebec, to protest against the violation of sovereign and sacred Native land, some of which white promoters wanted to turn into a golf course.

Stories need to be told more than once, in more than one language, and listening is crucial. Ondaatje's novel stresses our collectivity. "We are communal histories, communal books", says the writer, "[w]e are not owned or monogamous in our taste or our experience" (EP 261) nor better off for being monolingual, no matter how powerful a language may seem to be. Malouf configures a fictional translator who learns how to belong by listen- 
ing through an Aboriginal language, a 'minority tongue' from one point of view, but a truly planetary communication from another. This translator signals a willingness to 'approach' which is perhaps comparable to Gayatri Spivak's sense of "surrender" to the text, where "you have to be in a different relationship with the language, not even only with the specific text" (Spivak 2000: 400). In Malouf that 'specific text' is northern Queensland, and the different relationship requires the translator's desire to meet knowledge and encounter others as "the moon plucks at our world and all the waters of the earth ache towards it" ( $R B$ 200), an integration of language into the eco-system. Alex in Everything is Illuminated appears at first to be a comic cliché but there is much to be learned in the choices he makes as a translator. His wish to be "the kind of person who chooses for more than chooses against" (EiI 241) is a willingness to approach and engage that renders the translator a linguistic activist. Configured as collective, interdependent, or as an activist, the translator cannot operate autonomously. There is a message embedded in the figure of the fictional translator in anglophone writing: English can't go it alone, culturally or linguistically. The writers create damaged translators for damaged times, but as Stephen Ambrose (qtd. in Satterlee 2004: 171) has said, "the work of the next century is going to be restoration or it's not going to be anything at all".

\section{Bibliography}

\section{Primary texts}

Foer, Jonathan Safran (2002). Everything is Illuminated. Boston/New York: Houghton Mifflin.

Malouf, David (1993). Remembering Babylon. New York: Vintage.

Ondaatje, Michael (1994). The English Patient. Toronto: Vintage Books.

\section{Secondary texts}

Brennan, Timothy (2001). "The Cuts of Language: The East/West of North/South". Public Culture 13(1), 39-63.

Brittan, Alice (2002). "B-b-british Objects: Possession, Naming, and Translation in David Malouf's Remembering Babylon". PMLA 117(5), 1158-1171.

Chambers, Ross (1991). Room for Maneuver: Reading Oppositional Narrative. Chicago/London: University of Chicago Press.

Cronin, Michael (2000). Across the Lines: Travel, Language, Translation. Cork: Cork UP.

Cronin, Michael (2003). Translation and Globalization. London/New York: Routledge.

Derrida, Jacques (1998). Monolingualism of the Other; or, The Prosthesis of Origin (tr. Patrick Mensah). Stanford: Stanford UP.

Farrell, Stephen (2004). "Survival Guide to Working in a War Zone". The Times supplement, The Daily Yomiuri, September 12, 14.

Frazer, Liz (2002). "Everything is Illuminated" (review). Online at: 
http://www.book-club.co.nz/books03/8everythingilluminated.htm (consulted 14.02.2005).

Gentzler, Edwin \& Maria Tymoczka (2002). "Introduction". Translation and Power. Amherst/Boston: University of Massachusetts Press, xi-xxviii.

Gentzler, Edwin (2002). "What's Different about Translation in the Americas?". CTIS Occasional Papers 2, 7-17.

Goodall, Heather (1996). Invasion to Embassy: Land in Aboriginal Politics in New South Wales, 1770-1972. Saint Leonards: Allen.

Hermans, Theo (1996). "Norms and the Determination of Translation: A Theoretical Framework”. Román Álvarez \& M. Carmen-África Vidal (eds). Translation Power Subversion. Clevedon / Philadelphia / Adelaide: Multilingual Matters, 25-51.

Kincaid, Jamaica (1988). A Small Place. New York: Plume.

Kramsch, Claire (2002). "Alien Wisdoms in English and Foreign Language Programs". PMLA 117(5), 1245-1247.

Moore, David Chiomi (2001). "Is the Post- in Postcolonial the Post- in Post-Soviet? Toward a Global Postcolonial Critique". PMLA 116(1), 111-128.

Ondaatje, Michael (1978). "García Márquez and the Bus to Aracataca”. Diane Bessai \& David Jackel (eds). Figures in a Ground: Canadian Essays on Modern Literature Collected in Honor of Sheila Watson. Saskatoon: Western Producer Prairie Books, 19-31.

Papastergiadis, Nikos (1993). "David Malouf and Languages for Landscape: An Interview". Ariel: A Review of International English Literature 25(3) (July), 83-94.

Pound, Ezra (2000 [1929]) "Guido's Relations". Lawrence Venuti (ed.). The Translation Studies Reader. London/New York: Routledge, 26-33.

Pratt, Mary Louise (1992). Imperial Eyes: Travel Writing and Transculturation. New York: Routledge.

Pratt, Mary Louise (2002). "What's Foreign and What's Familiar?”. PMLA 117(5), 1283-1287.

Pratt, Mary Louise (2004). "Language, Liberties, Waves, and Webs - Engaging the Present". PMLA 119(3), 417-428.

Ram, Harsha (1995). "Translating Space: Russia's Poets in the Wake of Empire". Anuradha Dingwaney \& Carol Maier (eds). Between Languages and Cultures: Translation and Cross-Cultural Texts. Pittsburgh/London: University of Pittsburgh Press, 199-222.

Satterlee, Michelle (2004). "Seeing Local Nature: Interview with John Daniel". Interdisciplinary Studies in Literature and the Environment 11(2) (Summer), 167-179.

Shoemaker, Adam (1996). "Paper Tracks: Indigenous Literatures in Canada, Australia, and New Zealand". Bruce King (ed.). New National and PostColonial Literatures. Oxford: Clarendon Press, 245-262.

Spivak, Giyatri Chakravorty (2000). "The Politics of Translation”. Lawrence Venuti (ed.). The Translation Studies Reader. London/New York: Routledge, 397-416.

Stanton, Domna (2002). "From Imperialism to Collaboration: How Do We Get There?". PMLA 117(5), 1266-1271.

Venuti, Lawrence (2000). “1900s-1930s". Lawrence Venuti (ed.). The Translation Studies Reader. London/New York: Routledge, 11-14. 
